\title{
Exploring Verbal Relations between Arden of Faversham and John Lyly's Endymion
}

\author{
DARREN FREEBURY-JONES
}

The Shakespeare Birthplace Trust

Several scholars, utilizing traditional reading-based methods, have highlighted intertextual links between the anonymous domestic tragedy Arden of Faversham (1590) and John Lyly's comedy Endymion, The Man in the Moon (1588). The authorship of Arden of Faversham is fiercely contested: Brian Vickers and the present writer have argued for Thomas Kyd's sole authorship, whereas MacDonald P. Jackson and his New Oxford Shakespeare colleagues have contended for Shakespeare's part authorship. This article draws upon electronic corpora in order to highlight matching utterances between the Kentish tragedy and Lyly's comedy, and suggests that the quantity of rare and/or unique verbal parallels with Endymion is indicative of a single author's acquisitive practices. The article proceeds to explore these matches in context in order to broaden our understanding of the relations between these plays, and the composition of Arden of Faversham as a whole.

Plusieurs chercheurs ont mis en lumière, sur la base d'études de textes traditionnelles, des liens d'intertextualité entre la tragédie domestique anonyme Arden of Faversham (1590) et la comédie Endymion, The Man in the Moon (1588) de John Lyly. L'identification de l'auteur de la pièce Arden of Faversham fait l'objet d'une intense polémique. Brian Vickers et l'auteur de cet article ont défendu l'identification de Thomas Kyd comme seul auteur, alors que McDonald P. Jackson et ses collègues $d u$ projet New Oxford Shakespeare ont plutôt défendu Shakespeare comme l'un des auteurs. En s'appuyant sur des bases de données textuelles, cet article met en lumière une série d'occurrences communes aux deux ouvres, et propose que la quantité de ces recoupements verbaux rares et/ou uniques évoquent plutôt des pratiques spécifiques à un seul auteur. Cet article explore ensuite ces recoupements et les remet dans leur contexte afin d'enrichir notre compréhension des relations entre ces deux pièces, ainsi que la composition de la pièce Arden of Faversham en tant qu'ouvre en soi.

\section{The authorship of Arden of Faversham}

\footnotetext{
rden of Faversham (1590) was first entered in the Stationers' Register on 13 April $1592 .{ }^{1}$ It was published in quarto form that same year by Edward White. No extant edition of the play bears any indication of authorship. In

1. I have used Martin Wiggins and Catherine Richardson's British Drama 1533-1642: A Catalogue: Volume II: 1567-1589 (Oxford: Oxford University Press, 2012) and British Drama 1533-1642: A Catalogue: Volume III: 1590-1597 (Oxford: Oxford University Press, 2013) for the most likely dates of first performances.
} 
a general essay published in the Times Literary Supplement in $2008,{ }^{2}$ Brian Vickers, examining authorial self-repetition, concluded that Thomas Kyd was the play's sole author. Conversely, MacDonald P. Jackson has argued for Shakespeare's authorship of scenes 4 to 9 (the middle section of the play, or act 3 in older editions). He ascribes the rest of the play to an unknown co-author who was probably not Kyd. ${ }^{3}$ Jackson's part-ascription, ostensibly supported by computational stylistic tests conducted by Arthur F. Kinney, ${ }^{4}$ as well as Brett Greatley-Hirsch and Jack Elliott, ${ }^{5}$ has led to the inclusion of the domestic tragedy in The New Oxford Shakespeare. ${ }^{6}$ However, I contest Jackson and his colleagues' arguments, ${ }^{7}$ for I have discovered compelling evidence for Kyd's sole authorship of the play, encompassing verse style, the prosodic features of function words, rhyme forms, vocabulary, stage direction formulae, verbal links, and overall dramaturgy. ${ }^{8}$ Here I shall explore the possibility that the author (for the sake of clarity, I refer to the author/s of the domestic tragedy as "the dramatist" or "the author" throughout this article) of Arden of Faversham was influenced by John Lyly's Endymion, The Man in the Moon (1588). I propose that an analysis of the

2. Brian Vickers, “Thomas Kyd, Secret Sharer,” Times Literary Supplement (13 April 2008), 13-15.

3. See MacDonald P. Jackson, Determining the Shakespeare Canon: Arden of Faversham and A Lover's Complaint (Oxford: Oxford University Press, 2014).

4. See Arthur F. Kinney, "Authoring Arden of Faversham," in Shakespeare, Computers, and the Mystery of Authorship, ed. Hugh Craig and Arthur F. Kinney (Cambridge: Cambridge University Press, 2009), 78-99, 99.

5. See Brett Greatley-Hirsch and Jack Elliott, "Arden of Faversham, Shakespearean Authorship, and 'The Print of Many," in The New Oxford Shakespeare: Authorship Companion, ed. Gary Taylor and Gabriel Egan (Oxford: Oxford University Press, 2017), 139-81.

6. See Gary Taylor, John Jowett, Terri Bourus, and Gabriel Egan, eds., The New Oxford Shakespeare: Modern Critical Edition (Oxford: Oxford University Press, 2016).

7. See Darren Freebury-Jones, “Augean Stables; Or, the State of Modern Authorship Attribution Studies," Archiv fuer das Studium der Neueren Sprachen und Literaturen 255.1 (2018): 60-81.

8. See Darren Freebury-Jones, “'A raven for a dove': Kyd, Shakespeare, and the Authorship of Arden of Faversham's Quarrel Scene," Archiv fuer das Studium der Neueren Sprachen und Literaturen 253.1 (2016): 39-64; "Kyd and Shakespeare: Authorship versus Influence," Authorship 6.1 (2017), accessed 23 September 2018, authorship.ugent.be/article/view/4833; "Corresponding Stage Directions in Plays Attributable to Kyd," American Notes and Queries (forthcoming, 2018); "In Defence of Kyd: Evaluating the Claim for Shakespeare's Part Authorship of Arden of Faversham," Authorship (forthcoming, 2018); “The Diminution of Thomas Kyd," Journal of Early Modern Studies 8 (forthcoming, 2019). 
relationship between these plays may contribute to future studies concerning the authorship and composition of Arden of Faversham.

\section{Arden of Faversham and Endymion}

Several scholars have highlighted parallels between the anonymous Kentish tragedy and Lyly's Endymion. For example, Charles Crawford, arguing for Kyd's sole authorship of Arden of Faversham in 1906, stated that "Boas and others have pointed out Kyd's frequent imitations of John Lyly," so "we should not be surprised to find Lyly's similes and his Euphuistic mannerisms appearing also in Arden of Faversham." In 1901, Frederick S. Boas pointed out that Kyd's habit of starting lines with "Ay, but" is symptomatic of the dramatist's "distinctively Euphuistic mannerisms. Lyly is fond of making a statement and then contradicting it in a sentence beginning 'Ay, but.'" 10 There are nine instances of this colloquialism in Arden of Faversham, which we might compare with the six instances in Kyd's The Spanish Tragedy (1587), eight instances in Soliman and Perseda (1588), and seven instances in King Leir (1589). ${ }^{11}$ The latter play has been ascribed to Kyd by Edmond Malone, F. G. Fleay, J. M. Robertson, William Wells, Paul V. Rubow, Brian Vickers, Martin Mueller, and the present writer. ${ }^{12}$ Crawford highlighted verbal links between Arden of Faversham and Lyly's plays and concluded that "The proof lies before us here: the parallels from [...] Lyly are of an entirely different character from those I have adduced from Kyd

9. Charles Crawford, Collectanea: First Series (Stratford-upon-Avon: Shakespeare Head Press, 1906), $123-24$.

10. Frederick S. Boas, ed., The Works of Thomas Kyd (Oxford: Clarendon Press, 1901), xxiv.

11. It is worth noting, however, that Shakespeare's Henry VI Part Three (1591) contains eight instances of "Ay, but."

12. See Edmond Malone, The Plays and Poems of William Shakespeare, ed. James Boswell, 21 vols. (London: F. C. and J. Rivington, 1821), 2:316; F. G. Fleay, A Biographical Chronicle of the English Drama, 2 vols. (London: Reeves and Turner, 1891), 2:52; J. M. Robertson, An Introduction to the Study of the Shakespeare Canon: Proceeding on the Problem of Titus Andronicus (London: Routledge, 1924), 387; William Wells, “The Authorship of King Leir," Notes and Queries 25 (1939): 434-38; Paul V. Rubow, Shakespeare og hans samtidige (Copenhagen: Gyldendal, 1948): 145-55; Brian Vickers, "Secret Sharer" and "Kyd's Authorship of King Leir," Studies in Philology 115.3 (2018): 433-71; Martin Mueller, "Vickers is right about Kyd" and "N-grams and the Kyd Canon: A Crude Test," accessed 2 July 2016, brianvickers. uk/wp-content/uploads/2016/05/Martin-Mueller-on-Brian-Vickers-and-the-Kyd-canon.pdf; Darren Freebury-Jones, "In Defence of Kyd” and "The Diminution of Thomas Kyd." 
himself. I assert, then, that Kyd is the author of Arden of Faversham." ${ }^{13}$ A. F. Hopkinson also suggested that parts of the play seem to be distinctly under Lyly's influence, ${ }^{14}$ while Jackson, first arguing for Shakespeare's hand in the play in $1963,{ }^{15}$ noted that scene 11, in which Thomas Arden speaks of the Ferryman playing "the man in the moon," ${ }^{16}$ may provide an allusion to Lyly's play. He also highlighted Alice Arden's comparison between Thomas, the "silly man" that is her husband, and "lovely" Endymion ( $A F, 14.152-53)$. More recently, Ros King has pointed out that Lyly's play involves "the love of two rivals, Endymion and Tellus, for the moon," which mirrors "the liaisons in Arden." ${ }^{17}$

It is also worth noting that, in scene 3 of the tragedy, Michael's letter to Susan, which is a "travesty of euphuistic love language," 18 is used as a comic device. The letter shares Lyly's tendency for "rhetorical devices of alliteration, sentence balancing, proverbs, and similes culled from nature and fable." ${ }^{19}$ Lukas Erne observes that "Euphuism serves Kyd to characterize the languid, effeminate Petrarchan lover" Balthazar in The Spanish Tragedy. ${ }^{20}$ Both Michael and Kyd's Balthazar are used as pawns by the scheming villains Mosby and Lorenzo. Mosby's schemes are very similar to those hatched by Lorenzo in The Spanish Tragedy, for he effectively uses his sister, Susan, as bait, just as Lorenzo matches his sister with Balthazar to serve his own Machiavellian purpose. Mosby offers his sister in marriage and therefore pits Michael and Clarke against each other, rather like Lorenzo pits Pedringano and Serberine against each other. We can

13. Crawford, 130 .

14. See A. F. Hopkinson, ed., Shakespeare's Doubtful Plays (London: M. E. Sims, 1907).

15. See MacDonald P. Jackson, "Material for an Edition of Arden of Faversham" (B.Litt. thesis, Oxford University, 1963), 77.

16. Arden of Faversham, 11.27-28, in The Tragedy of Master Arden of Faversham, ed. M. L. Wine (London: Methuen, 1973). All further references are to this edition and will be given parenthetically.

17. Ros King, "Arden of Faversham: The Moral of History and the Thrill of Performance," in The Oxford Handbook of Tudor Drama, ed. Thomas Betteridge and Greg Walker (Oxford: Oxford University Press, 2012), 635-52, 647.

18. Kathleen E. McLuskie and David Bevington, "Introduction," in Plays on Women, ed. Kathleen E. McLuskie and David Bevington (Manchester: Manchester University Press, 1999), 1-60, 34.

19. Wine, ed., 46.

20. Lukas Erne, Beyond The Spanish Tragedy: A Study of the Works of Thomas Kyd (Manchester: Manchester University Press, 2001), 71. 
therefore discern some similarities between the parody of Lyly's euphuistic style in Arden of Faversham and Kyd's use of euphuism elsewhere.

With the exception of Crawford, none of the aforementioned scholars has explored the possibility that Lyly's influence on Arden of Faversham can provide clues to the play's authorship. Rather, the "literary echoes" from Endymion have generally been cited in order to date the Kentish tragedy to "the late 1580s" or early $1590 \mathrm{~s}^{21}$ Literary indebtedness between these texts can be measured in a variety of ways, be it through allusions to Lyly's comedy, such as those identified by Jackson, studies of similarities in dramatic structure and characterization, and explorations of the ways in which the dramatist parodied Lyly's style. Here I focus specifically on n-grams (contiguous word sequences) shared between these texts, and argue that the dramatist responsible for Arden of Faversham not only alluded to and parodied Lyly's comedy, but borrowed a large number of phrases from the play. I focus specifically on verbal links because they are quantifiable, and because matching utterances can be subjected to qualitative analysis (i.e., close study of their contextual similarities), which may give us an insight into the dramatist's thought processes and patterns of borrowing.

\section{Overall repetitions in Arden of Faversham (1552-1662)}

The latest scholar to provide evidence that the dramatist responsible for Arden of Faversham borrowed from Lyly's Endymion is Martin Mueller, who has created an electronic corpus called Shakespeare His Contemporaries, consisting of over five hundred plays dated between 1552 and 1662. All n-grams shared between plays in this corpus, from bigrams (two-word units) upwards, are electronically tagged using a program called MorphAdorner, developed by Philip R. Burns. ${ }^{22}$ Mueller explains that

The program that identifies repeated $\mathrm{n}$-grams is given a list of the lemmata [a lemma is a word considered as its citation form and all inflected forms] of all spoken words in sequence. It ploughs through that list, mindlessly matching cases for repeated sequences of the same lemmata $[\ldots]$ the real

21. See Gary Taylor and Rory Loughnane, "The Canon and Chronology of Shakespeare's Works," in The New Oxford Shakespeare: Authorship Companion, 417-602, 488.

22. See MorphAdorner V2.0, on the Northwestern University Information Technology website, accessed 6 May 2017, morphadorner.northwestern.edu/morphadorner/postagger/. 
power of the program comes from the aggregation of the data, which lets you compare the relative frequency of shared n-grams. In practice, the cases missed by the program don't add up to a lot, so that frequency-based conclusions are almost never thrown off. ${ }^{23}$

Shakespeare His Contemporaries enables users to generate spreadsheets that rank play pairs according to shared repetitions tagged by MorphAdorner. It is worth observing that several of Lyly's plays feature in Mueller's list of texts sharing the densest verbal relations with Arden of Faversham, according to overall repetition counts (irrespective of whether these repetitions are unique or common), as well as those weighted according to rarity and the lengths of word strings. Lyly's Gallathea (1588) is ranked eighteenth; Mother Bombie (1589) is ranked twenty-ninth; and The Woman in the Moon (1588) is ranked thirtyfirst (this spreadsheet contains a total of 182 pairwise combinations involving Arden of Faversham), ${ }^{24}$ which suggests that the dramatist responsible for Arden of Faversham was conscious of Lyly's idiom. Notably, this list is headed by Kyd's Soliman and Perseda; King Leir is ranked ninth; Fair Em (1590), another play Vickers ascribes to Kyd, ${ }^{25}$ is ranked tenth; while Richard III (1593), the Shakespeare play with the most verbal affinities with the domestic tragedy, is ranked thirteenth. The data thus demonstrate that some of the plays Vickers and the present author assign to Kyd have denser verbal relations with Arden of Faversham than any Shakespeare text, which would seem to support an attribution to Kyd.

\section{Unique tetragrams-plus in Arden of Faversham and Endymion (1552-1662)}

I have profited much from Mueller's spreadsheet, "SHCSharedTetragramsPlus,"26 which lists play pairs that share large numbers of unique tetragrams-plus

23. Email correspondence, 2 February 2016.

24. I should like to thank Martin Mueller for sending me a document, entitled "Ardenpairwisevalues," containing this data (email correspondence 19 July 2016). I have made all of Mueller's spreadsheets relating to the "extended" Kyd canon available on my website: darrenf.wordpress.com/2017/11/, accessed 23 September 2018.

25. See Vickers, "Secret Sharer"; see also Darren Freebury-Jones, "Possible Light on the Authorship of Fair Em," Notes and Queries 64.2 (2017): 252-54.

26. Martin Mueller, "Repeated n-grams in Shakespeare His Contemporaries (SHC)," accessed 13 December 2014, scalablereading.northwestern.edu/?p=312. 
(sequences consisting of four words or more). Mueller notes that "it is quite rare for two plays-texts that are typically between 15,000 and 25,000 words long-to share more than one or two of the dislegomena [a sequence of words that occurs within only two plays in Mueller's machine-readable corpus] analyzed here." ${ }^{27}$ Mueller also observes that "If we look more closely at shared dislegomena" consisting of at least four words "by same-author play pairs, we discover that on average plays by the same author share five dislegomena, and the median is four. Roughly speaking, plays by the same author are likely to share twice as many dislegomena as plays by different authors." ${ }^{28}$ Mueller has discovered that 4,629 pairwise combinations in his corpus share seven or more dislegomena, and 22 percent of these combinations involve plays by the same author. Mueller's corpus therefore creates "a framework of expectations" within which the evidence of longer word sequences can be evaluated. ${ }^{29}$ Shakespeare His Contemporaries provides evidence for common authorship of texts sharing large numbers of tetragrams-plus, but the corpus also provides quantitative data indicative of verbal borrowing (indeed, all too many modern attribution scholars make arguments for authorship purely on the basis of quantities of parallels, without properly reviewing the evidence for influence). Tetragramsplus are useful for exploring the influence that one play had on another because "larger phrasal structures are open to appropriation, imitation and parody" 30 I have therefore limited my analysis of shared phrases between Arden of Faversham and Endymion to n-grams consisting of at least four words, thus also taking into account pentagrams (five-word units), hexagrams (six-word units), and so forth, in order to explore the notion that the author of the domestic tragedy appropriated phrases from Lyly's comedy. These are strictly contiguous sequences, although some of the matching utterances embrace additional words in a similar syntactical and/or semantic structure.

Mueller's spreadsheet, "SHCSharedTetragramsPlus," reveals that there are seven unique phrases shared between the Kentish tragedy and Lyly's Endymion. Are we to suppose that both Shakespeare and his co-author uniquely

27. Mueller, "Repeated n-grams."

28. Mueller, "Repeated n-grams."

29. Mueller, "Repeated n-grams."

30. Brian Vickers, "Identifying Shakespeare's Additions to The Spanish Tragedy (1602): A New(er) Approach," Shakespeare 8 (2012): 13-43, 23. 
appropriated large phrasal structures from Lyly's comedy? Significantly, we do not find a high quantity of matches between Shakespeare and Lyly's comedy in Mueller's corpus until Cymbeline (1610). ${ }^{31} \mathrm{I}$ consider it unlikely that Shakespeare and a collaborating author would select Lyly's comedy to inform the verbal details of their respective portions of a domestic tragedy.

However, there can be little doubt that Shakespeare was influenced by Lyly. Indeed, G. K. Hunter argued that Shakespeare's A Midsummer Night's Dream (1595) is "in the manner of Lyly," and that Love's Labour's Lost (1596) is "completely Lylian" in its construction, ${ }^{32}$ while Kenneth Muir contended that "Many characteristics of Shakespearean comedy can be traced to Lyly-wit combats, the disguising of girls as boys, mischievous pages, interspersed songs, and many other things." ${ }^{33}$ Gary Taylor and Rory Loughnane state that The Two Gentlemen of Verona (1594) is "demonstrably indebted to the idiosyncratic prose style of John Lyly," and in particular "Lyly's bestseller Euphues." ${ }^{34}$ Scholars such as Alfred Harbage, ${ }^{35}$ Leah Scragg, ${ }^{36}$ and David Bevington, ${ }^{37}$ to instance just a few examples, have also explored Shakespeare's relationship with Lyly's drama. Nonetheless, for all the dramatic parallels between Shakespeare and Lyly's comedies, Mueller's spreadsheet provides no evidence that Shakespeare frequently borrowed large phrasal units from Lyly's Endymion at the very beginning of his career. (Notably, King Leir, which I attribute to Kyd, also shares seven unique n-grams with Lyly's play; such patterns of influence could be explained by the theory that the same dramatist was responsible for both plays.)

31. My colleague Johann Gregory has suggested in personal correspondence (16 November 2015) that "Cymbeline seems to be harking back to these earlier Romances of Lyly's" performed by the Children of Paul's at Blackfriars Theatre. He notes that "Cymbeline was written for the Globe but (unlike Pericles) also for Blackfriars, which the King's Men had just started performing in.” Perhaps Shakespeare, mindful of genre and audience expectations, consulted Lyly's drama as he composed Cymbeline.

32. G. K. Hunter, John Lyly: The Humanist as Courtier (London: Harvard University Press, 1962), 318.

33. Kenneth Muir, The Sources of Shakespeare's Plays (London: Routledge, 1977), 8.

34. Taylor and Loughnane, 485.

35. See Alfred Harbage, “Love's Labour's Lost and the Early Shakespeare," Philological Quarterly 41 (1962): 18-36.

36. See Leah Scragg, The Metamorphosis of Gallathea: A Study in Creative Adaptation (Washington, DC: University Press of America, 1982).

37. See David Bevington, “'Jack hath not Jill’: Failed Courtship in Lyly and Shakespeare," Shakespeare Survey 42 (1990): 1-14. 
Given that the total for unique phrases between the domestic tragedy (which likely antedated Shakespeare's entire corpus) and Endymion exceeds the norm for same-author play pairs, we can be confident that Mueller's Shakespeare His Contemporaries consolidates the theory expounded by previous scholars that the author of Arden of Faversham was influenced by Lyly's comedy.

I shall now study some of these matching utterances in context (all of which, to reiterate, are unique in Mueller's corpus of over five hundred plays), in order to expand our knowledge of the nature of verbal links between these texts. The first unique shared phrase between Arden of Faversham and Endymion occurs when Alice Arden soliloquizes:

\section{Sweet Mosby is the man that hath my heart;}

And he usurps it, having nought but this. (AF, 1.98-99)

In Lyly's comedy, Tellus tells the audience that

\section{Endymion, sweet Endymion, is he that hath my heart. ${ }^{38}$}

Here we find an unmistakeable verbal match that far exceeds the bounds of coincidence: the consecutive cluster of four words, "that hath my heart," embracing the verb "is," the adjective "sweet," and the pronoun "he." This is the first, albeit inexplicit, comparison between Mosby and Lyly's Endymion figure. Moreover, it seems that the author of Arden of Faversham was somewhat influenced by Tellus in his characterization of Alice. In Lyly's play, Tellus is cast "as a Circean enchantress" who seeks to ensnare Endymion, ${ }^{39}$ and Floscula advises her against "love gotten with witchcraft" (End., 1.2.81-82), for there "cannot be a thing more monstrous than to force affection by sorcery" (End., 1.4.6-7). Similarly, in the famous Quarrel Scene (scene 8), which Jackson ascribes to Shakespeare, Alice's lover, Mosby, claims he is "bewitched," and rues "the hapless hour" that Alice "enchanted" him ( $A F, 8.78-80)$. The same thought process can be seen in the first quarrel (in scene 1) between Alice and Mosby in the play, which Jackson assigns to an unknown co-author, when Alice

38. John Lyly, Endymion, The Man in the Moon, 1.4.37, in Endymion, ed. David Bevington (Manchester: Manchester University Press, 1996). All further references are to this edition and will be given parenthetically.

39. David Bevington, "Introduction," in Endymion, ed. David Bevington, 1-72, 18. 
accuses Mosby of conquering her through "witchcraft and mere sorcery" ( $A F$, 1.200). In scene 8 , Mosby displays rhetorical legerdemain by using Alice's own accusations in the first quarrel against her.

In the opening conflict between the lovers, Mosby is cold towards Alice, ostensibly in order to test her loyalty, to which Alice responds: "For what hast thou to countenance my love" ( $A F, 1.201)$. Here she is mocking Mosby as a "Base peasant" ( $A F, 1.198)$ who, as we have seen, has supposedly managed to woo her away from her married state through occult arts. Evidence that the author had Endymion in mind when writing these quarrel scenes can be found in the matching discontinuous six-word sequence below:

for what hast thou found in my life but

love? (End., 5.4.233-34)

Following this first quarrel and subsequent reconciliation, Mosby (through a combination of manipulation and Thomas Arden's foolhardiness) manages to convince Alice's husband that he should frequent his house while he is away:

By my faith, sir, you say true.

And therefore will I sojourn here a while. (AF, 1.353-54)

These lines echo the Watchman's dialogue in Lyly's play:

Nay he says true; and therefore till Cynthia

have been here. (End., 4.2.118-19)

Many of the phrases shared between Arden of Faversham and Endymion occur within lines spoken by the lovers. However, the dramatist responsible for Arden of Faversham did not reserve Lyly's phrases solely for these characters. The murderers, Black Will and Shakebag, repeat divine Cynthia's dialogue in scene 9 of Arden of Faversham, which Jackson assigns to Shakespeare. Shakebag and Will engage in a foolish verbal bout, the former stating, "Why he begun," to which the latter responds: "And thou shalt find I'll end" $(A F, 9.35)$. Cynthia proceeds to restore Endymion's youthful looks: "thou hast begun, and thou shalt find" (End., 5.4.179). Although this pentagram is unique in early modern drama, the repetition in Arden of Faversham is contextually dissimilar, 
suggesting that many elements of Lyly's phraseology were embedded in the tragedian's verbal memory as he composed the play.

A more striking match occurs in the subsequent scene of the Kentish tragedy, when Alice says,

\section{for what is life but love?}

And love shall last as long as life remains. (AF, 10.88-89)

Alice's interrogative matches Eumenides's in terms of idiom and structure:

for what hast thou found in my life but

love? And as yet what have I found in my love but bitterness? (End., 5.4.233-34)

This cluster of seven identical words provides firm evidence that the author of Arden of Faversham recalled the verbal details of Lyly's play (as I showed above, Alice had already echoed these lines in scene 1). Perhaps he somehow possessed a copy of the text prior to publication, or remembered Lyly's lines from having seen the play during performance. As John Tobin notes, the early modern period "was a time when the aural rather than the visual understanding was much greater than in our own time." ${ }^{40}$

In scene 13 of the domestic tragedy, Dick Reede curses Arden:

And thus I go but leave my curse with thee. $(A F, 13.53)$

Arden has procured Reede's land, which is a "crime" that "God will justly punish." 41 The numerous failed attempts on Arden's life emphasize "the potency of Dick Reede's appeals to divine justice by foregrounding the haste with which his requests are realized." 42 Lyly's braggart, Sir Tophas, claims that his "words" have the power to "wound" (End., 1.3.61). But Tophas, who delivers "singularly

40. John Tobin, "Elizabethan Theater," in Hamlet: Evans Shakespeare Editions, ed. John Tobin (Boston, MA: Wadsworth, 2012), 15-26, 22.

41. Miles S. Drawdy, “'See here my show': Providence and The Theatrum Mundi in Thomas Kyd's The Spanish Tragedy" (Honors thesis, College of William and Mary, Virginia, 2014), 24, accessed 9 July 2015, publish.wm.edu/cgi/viewcontent.cgi?article=1001\&context=honorstheses.

42. Drawdy, 23. 
foolish" epithets and "composes fatuous verses,"43 is linguistically impotent in comparison to the revenger figure of Reede, whose invocation of divine forces leads to Arden's long-awaited demise. The following lines nonetheless anticipate Reede's vow (we might also note the presence of personal pronouns "you" and "thee"): "and thus I go as you see, clothed with artillery" (End., 1.3.53-54). Following Arden's brutal death, Alice pretends to be concerned about her husband's whereabouts:

Ah, neighbours, a sudden qualm came over my heart. $(A F, 14.302)$

The author seems to have remembered Eumenides's complaint in Endymion when he composed Alice's speech:

Yes Father, but a qualm that often commeth over my heart. (End., 3.4.37-38)

It is perhaps worth noting the co-occurrence of the trigram (three-word unit), "a sudden qualm," in Kyd's Soliman and Perseda: "A suddaine qualme; I therefore take my leave." ${ }^{44}$ The co-occurrence of all these n-grams, unique in Mueller's corpus of over five hundred plays, suggests that scholars such as Crawford and Jackson were correct in suggesting that the author of Arden of Faversham was influenced by Lyly's play, but that they did not recognize the full extent to which these plays share verbal affinities.

\section{Rare Tetragrams-plus in Arden of Faversham and Endymion (1580-1600)}

Shakespeare His Contemporaries encompasses plays written within, roughly, a hundred year period, whereas the rare parallels I explore below occur within what Jackson refers to as "an appropriate time frame," namely 1580 to 1600 , therefore taking into account the likely first performance of Lyly's play at Greenwich Palace in 1588, its publication in 1591, and the publication of Arden of Faversham in $1592 .{ }^{45}$ Pervez Rizvi has developed an electronic corpus

43. Bevington, "Introduction," 42.

44. Soliman and Perseda, 2.1.50, in Boas, ed.

45. Jackson, Determining, 16. 
of 527 plays drawn from Mueller's corpus and the Folger Shakespeare Library Editions website, ${ }^{46}$ dated between 1552 and 1657, titled Collocations and $\mathrm{N}$-grams ${ }^{47}$ Rizvi generated a spreadsheet listing every phrase consisting of four or more identical words shared between Endymion and other plays. ${ }^{48}$ I drew up a list of verbal matches that occur no more than five times in plays first performed during 1580-1600, through filtering the data in this spreadsheet. A study of rare shared phrases, in comparison to other dramatists who employed verbal formulae found in Lyly's comedy, could therefore help to broaden our understanding of the patterns of verbal borrowing in Arden of Faversham.

In total, there are twenty rare phrases consisting of four or more identical words shared between Arden of Faversham and Endymion. King Leir also shares twenty exact tetragrams-plus that occur no more than five times in the specified period. If we adjust these figures according to composite word counts, we find that both plays average 0.05 rare matches with Lyly's text. In my view, the quantity of rare parallels provides complementary evidence-alongside the evidence for internal repetition, verse style, prosody etc. that I have presented elsewhere ${ }^{49}$ - that Arden of Faversham is a uniform play belonging to a single authorial mind. The patterns of influence, like all the other data I have collected, do not appear to support Jackson, Kinney, and Jackson's New Oxford Shakespeare colleagues' hypothesis that the play is the product of Shakespeare and an unknown co-author. Having tested Shakespeare's earliest plays, according to Wiggins's chronology, in the same way, I found that they had statistically significant lower percentages. For instance, The Taming of the Shrew (1592) averages 0.03 matches. Conversely, Arden of Faversham and King Leir are strikingly homogenous in terms of the high rates in which they recycle Lyly's phraseology.

At the beginning of the Kentish tragedy, Thomas Arden accuses Alice of dreaming of Mosby:

46. Folger Shakespeare Library Editions, online, accessed 23 September 2018, folger.edu/folger-shakespearelibrary-editions.

47. Shakespeare's Text, online, accessed 23 September 2018, shakespearestext.com/can/index.htm.

48. I am grateful to Pervez Rizvi for sharing this data with me (email correspondence, 6 May 2017 and 21 September 2018).

49. See Freebury-Jones, "A raven for a dove" and "In Defence of Kyd." 
I heard thee call on Mosby in thy sleep. $(A F, 1.66)$

This line uniquely parallels Geron's exchange with Eumenides, "for so I heard thee call thyself" (End., 3.4.87-88), and we might note the association of this word sequence with dreams in the subsequent line: "I think thou dreamest" (End., 3.4.89). The slight similarities in context here provide additional evidence that the author of Arden of Faversham recalled Lyly's play. It is also worth pointing out the determiner "thy" and the pronoun "thyself" in these examples.

When the bumbling murderer, Black Will, speaking in prose, says,

Ah that I might be set awork thus through the year $(A F, 2.105-06)$

he is, as we saw with Alice and Mosby above, echoing Tellus:

Ah, that I might once again see. (End., 4.1.14)

Black Will desires to make murder a stable occupation, whereas Tellus desires to see her former beloved, Endymion. The context is different, but the word string is nevertheless unique in the period 1580-1600. In scene 9, these murderers prepare to slay Arden, but they are interrupted by Lord Cheyne and his men. Arden, unaware that Black Will and Shakebag are spying on him, entreats his companion, Franklin, to continue telling a tale about an accused wife. In Lyly's play, Geron is married to the enchantress, Dipsas, and there could conceivably have been some association in the author's mind between this character relationship and Thomas Arden's marriage to a wife who is accused of having powers of enchantment. Several lines later, Arden salutes Lord Cheyne thus: "Your honour's always! Bound to do you service!" ( $A F, 9.101)$. This fourword unit features in Lyly's Endymion (it also co-occurs with Shakespeare's A Midsummer Night's Dream, which seems to have been written several years later than the Kentish tragedy), when Dares tells Tophas he is "ready to do you service" (End., 3.4.101). The close proximity of this matching utterance with the formula, "begun and thou shalt find," noted above, suggests that Lyly's dramatic language was at the forefront of the dramatist's mind when he wrote these lines. 
The following word string is, in my view, undoubtedly borrowed from Lyly. Alice fantasizes about her husband's imminent murder, and says that Mosby

Shall compass me; and were I made a star,

I would have none other spheres but those. (AF, 14.146-47)

It can hardly be coincidence that the formulation, "I would have none," which can be found in the following speech in Endymion,

\section{I would have none partaker of my}

sweet love (End., 4.1.70-71)

features within the same speech in Arden of Faversham where we find perhaps the most explicit allusion to Lyly's comedy in the whole play: "Not half so lovely as Endymion" ( $A F, 14.153)$. This tetragram can also be found in Lyly's Campaspe (1583), and no other play first performed during the period 1580-1600. Finally, for the ending of Arden of Faversham, the author may have recollected Tellus's "remembrance of the end" (End., 1.2.71), to which Floscula responds: "Why, if this be not the end, all the rest is to no end" (End., 1.2.72). Franklin, serving as epilogue, shares the unique tetragram, "the rest is to," embracing "this" and "be," with Lyly's comedy: "But this above the rest is to be noted" (AF, Epilogue.9). The exchange between Tellus and Floscula concerns the themes of death and divine judgment, while, in Arden of Faversham, Franklin emphasizes that divine retribution has been accomplished by describing the punishments that the villains of the play (including Black Will, who was murdered, and Shakebag, who was burnt at the stake) suffered.

I have thus tested the rarity of verbal formulae shared between Arden of Faversham and Endymion, in comparison to "all dramatists within" the "appropriate time frame" 1580-1600 who might also have "used them." ${ }^{0}$ The uncommonness of these parallels, many of which are contextually similar, strongly suggests that the author of the domestic tragedy was conscious of Lyly's dramatic language. 


\section{Overview of results}

In this article I have demonstrated that Arden of Faversham - when tested against over five hundred plays in Mueller's corpus Shakespeare His Contemporariesshares a large number of $\mathrm{n}$-gram repetitions with several Lyly plays. Moreover, I have shown that the Kentish tragedy shares a statistically significant number of unique tetragrams-plus in this corpus with Lyly's Endymion. Following Jackson's criteria, I restricted the time frame to the period 1580-1600 (thus taking into account the most likely dates these plays were first performed) and discovered that the quantity of tetragrams-plus occurring no more than five times in plays of the period points towards a non-Shakespearean author's patterns of verbal borrowing. However, verbal relations between Endymion and the domestic tragedy are akin to those found for Lyly's play and the anonymous King Leir, which I ascribe to Thomas Kyd. These results may therefore contribute to future discussions on the authorship of Arden of Faversham. It seems that scholars like Jackson and Crawford were correct in identifying a relationship between these texts, for the evidence that the dramatist responsible for Arden of Faversham had either seen or read Lyly's comedy seems solid. 